\title{
Optimisation of the Regulatory Regime and its Impact on Women Empowerment-A Case Study of Karnataka
}

\author{
Seema Sinha
}

\begin{abstract}
Micro-finance seems to be doing much better than what the rural branches of commercial banks and branches of rural banks (RRBs) did when they set out to financially assist the vulnerable sections of society particularly those sections that lived in villages. Unlike the commercial bank branches and the RRB branches, micro-finance institutions cater exclusively to the needs of those who are financially excluded. They seek to finance those who have been denied finance by the formal and institutional financial sector. Unlike commercial bank branches and RRB branches which insist on comprehensive documentation to ensure that they can access legal remedy against the defaulting borrowers, the micro-finance institutions rely upon peer pressure to minimise delinquency. Thus a small group of borrowers, numbering, say, 20, is financed one at a time. Once the first borrower repays the loan, the next qualifying beneficiary is sanctioned loan. Any delay on the part of the first borrower to repay the loan inevitably leads to a delay in the release of the loan to the beneficiary next in line. Hence there is peer pressure always at work which by and large helps the MFI to recover its loan in as amicable a manner as possible. The borrower, apart from the legal obligation to repay the loan, is also under a moral obligation to service the loan promptly. The operations of MFIs in rural India have, to a certain extent, reduced the dependence of the beneficiaries on the local moneylenders for financial assistance. This is all the more significant when the beneficiaries happen to be women since women and in particular rural women figure among the most vulnerable and by extension, most exploited sections of the country in general and rural India in particular. The financial assistance extended by MFIs has made them financially independent thereby rendering them invulnerable to exploitation by vested interests. The presence of the locals in the teams deputed by MFIs to disburse loans and recover the disbursed loans has struck a chord with the rural beneficiaries. Strangely, the higher rate of interest applied by the MFIs to the loans raised by the beneficiaries does not seem to have affected the recovery of loans. Apparently, the rate of interest applied to their loans does not seem to affect the borrowers much. This only shows that small borrowers are as "bankable" as the so-called creditworthy borrowers the commercial banks finance in urban India. It also lays to rest the commonly held belief of the bankers that secured loans seldom fail and unsecured loans often fail. What this implies is that it is the borrower's character more than the security that the borrower furnishes, that determines the borrower's adherence to repayment ethics. Even in the real world situation, one comes across huge loans backed by huge securities have not helped the commercial banks reduce their NPA levels. The loans still remain unrecovered and the assets the loans helped create, are gradually turning into scrap heaps. On their part, MFIs can periodically design the products they offer to the beneficiaries. In fact, they can waive the margin requirement in respect of first-time borrowers. After availing of the loan, the first-time borrower would be in a better position to furnish margin money in respect of the loan applied for. Many beneficiaries who have borrowed from MFIs admit at least in private that their association with the MFIs has helped them in several ways: their standing in society has gone up; they are able to educate their children; they are able to access nutritious food.
\end{abstract}

Keywords: Bankable; commercial banks; creditworthy; MFIs, peer pressure; RRBs, standing

\section{Introduction}

Development is the ideal answer to Indiaes rural poverty and by extension to the country's poverty as a whole. Given that India lives in its villages as the Father of the Nation rightly remarked, any measure that seeks to address India's economic problem will do well by first addressing the problems that come in the way of rural development. There are some inherent factors planners can exploit to achieve rural development. To improve the rural economy, capital-intensive projects are not required. State-of-the-art technology is not required. Skilled human resources are not required. A mix of semi-skilled and unskilled human resources is good enough to trigger rural development. Rural development-oriented projects can exploit local technology and by definition, this technology is labour-intensive. Thus employment generation can be ensured simultaneously. All these measures, if implemented seriously, can trigger rural development.

\section{Problems of Rural India}

Rural Indiacs problems are unique. The rural-urban divide is still conspicuous in India although the powers that be may claim otherwise. Unfortunately, the rural-urban divide is talked of only in terms of digital divide, relegating to the background, the more important rural-urban divide per se No conscious efforts are being made by the government, central or state, to bridge the divide. In some states of India like Kerala, Tamilnadu, Maharashtra and Gujarat, the urbanrural divide is slowly reducing not because of the government but in spite of the government. In the said states, rapid urbanisation has been reducing this divide.

Inadequate investment in social infrastructure has been the bane of India in general and rural India in particular. Social infrastructure inadequacies of urban India draw the attention of the government first, state or central. Only then social infrastructure inadequacies of rural India are reckoned. In the circumstances, the rural-urban divide will continue to be the bane of rural India for quite some time to come. If economic development is to take place, industrial infrastructure has to be complemented by social infrastructure. This also explains why some countries have witnessed a healthy economic growth while others have lagged behind. In developed economies, social infrastructure stands out. It is against this stark reality that the problems of rural India should be viewed and tackled.

While informal financial services have always been an integral part of the traditional economy of India , even semi- 


\section{International Journal of Science and Research (IJSR) \\ ISSN (Online): 2319-7064 \\ Index Copernicus Value (2013): 6.14 | Impact Factor (2014): 5.611}

formal and formal financial services through agricultural cooperatives and banks are within physical reach (less than 5 $\mathrm{km}$ ) of perhaps 99 per cent of the population of the country (Ghate, 1992). A good number of commercial banks, cooperative banks and regional rural banks (RRBs) on the one hand and other financial institutions (FIs) on the other hand, provide such services these days, the non-bank finance companies (NBFCs) being notable amongst the latter category.

The two decades of IRDP experience - in the 1980s and 1990 s - affected the credibility of micro-borrowers from the perspective of bankers and, ultimately, restricted the access of the usually less-literate poor to banking services. Thus, the entire network of primary cooperatives in the country and the RRBs, entrusted with addressing the financial needs of the rural sector in general and the poor, in particular, proved a colossal failure. Saddled with directed credit and a restrictive interest-rate regime, the financial health of the RRBs deteriorated quickly while the cooperatives suffered from their usual malaise of mismanagement, privileged leadership and corruption born of excessive state patronage and protection

\section{Measures Adopted by Central and State Governments to Empower Women}

The Ministry of Women \& Child Development (W\&CD) was set up in the year 1985 as a part of the Ministry of Human Resource Development to give the much-needed impetus to the holistic development of women and children. On 30.01.2006, the department was upgraded into a ministry.

\section{a) Mandate}

The broad mandate of the ministry is to ensure holistic development of women and children. As the nodal ministry for the advancement of women and children, the ministry formulates plans, policies and programmes; enacts/ amends legislation, guides and coordinates the efforts of both governmental and non-governmental organisations working in the field of women and child development. These programmes play a supplementary and complementary role to the other general developmental programmes in the sectors of health, education, rural development, etc. All these efforts are directed to ensure that women are empowered both economically and socially and thus become equal partners in national development along with men.

\section{b) Economic Empowerment of women}

Since women comprise the majority of the population below the poverty line and are very often in situations of extreme poverty, given the harsh realities of intra-household and social discrimination, macroeconomic policies and poverty eradication programmes will specifically address the needs and problems of such women. There will be improved implementation of programmes which are already women oriented with special targets for women.

\section{c) Micro Credit}

In order to enhance women's access to credit for consumption and production, the establishment of new and strengthening of existing micro-credit mechanisms and microfinance institution will be undertaken so that the outreach of credit is enhanced. Other supportive measures would be taken to ensure adequate flow of credit through extant financial institutions and banks, so that all women below poverty line have easy access to credit.

\section{d) Women and Economy}

Women's perspectives will be included in designing and implementing macro-economic and social policies by institutionalizing their participation in such processes. Their contribution to socio-economic development as producers and workers will be recognized in the formal and informal sectors (including home based workers) and appropriate policies relating to employment and to her working conditions will be drawn up. Such measures could include:

- Reinterpretation and redefinition of conventional concepts of work wherever necessary e.g. in the Census records, to reflect women 's contribution as producers and workers.

- Preparation of satellite and national accounts.

- Development of appropriate methodologies for undertaking (i) and (ii) above.

\section{e) Globalization}

Globalization has presented new challenges for the realization of the goal of women's equality, the gender impact of which has not been systematically evaluated fully. However, from the micro-level studies that were commissioned by the Department of Women \& Child Development.

\section{f) Women and Agriculture}

In view of the critical role of women in the agriculture and allied sectors, as producers, concentrated efforts will be made to ensure that benefits of training, extension and various programmes will reach them in proportion to their numbers. The programmes for training women in soil conservation, social forestry, dairy development and other occupations allied to agriculture like horticulture, livestock including small animal husbandry, poultry, fisheries etc. will be expanded to benefit women workers in the agriculture sector.

\section{g) Women and Industry}

The important role played by women in electronics, information technology and food processing and agro industry and textiles has been crucial to the development of these sectors. They would be given comprehensive support in terms of labour legislation, social security and other support services to participate in various industrial sectors.

Women at present cannot work in night shift in factories even if they wish to. Suitable measures will be taken to enable women to work on the night shift in factories. This will be accompanied with support services for security, transportation etc.

\section{h) Support Services}

The provision of support services for women, like child care facilities, including crèches at work places and educational institutions, homes for the aged and the disabled will be expanded and improved to create an enabling environment and to ensure their full cooperation in social, political and economic life. Women-friendly personnel policies will also be drawn up to encourage women to participate effectively in the developmental process.

\section{Volume 5 Issue 2, February 2016}




\section{International Journal of Science and Research (IJSR)}

ISSN (Online): 2319-7064

Index Copernicus Value (2013): 6.14 | Impact Factor (2014): 5.611

Social Empowerment of Women

1) Education

Equal access to education for women and girls will be ensured. Special measures will be taken to eliminate discrimination, universalize education, eradicate illiteracy, create a gender-sensitive educational system, increase enrolment and retention rates of girls and improve the quality of education to facilitate life-long learning as well as development of occupation/vocation/technical skills by women. Reducing the gender gap in secondary and higher education would be a focus area.

2) Environment

Women will be involved and their perspectives reflected in the policies and programmes for environment, conservation and restoration. Considering the impact of environmental factors on their livelihoods, women "s participation will be ensured in the conservation of the environment and control of environmental degradation. Women will be involved in spreading the use of solar energy, biogas, smokeless chulahs and other rural application so as to have a visible impact of these measures in influencing eco system and in changing the life styles of rural women.

\section{Advent of the MFI players}

To fill the vacuum occasioned by the collapse of the RRBs, a semi-formal NGO-MFI sector arrived. It has been evolving too over the past 20-25 years. Organisations such as the SEWA Bank (Ahmedabad), Annapurna Mahila Mandal (Mumbai) and Working Women's Forum (Chennai) pioneered the new channel. The movement picked up steam during the $1990 \mathrm{~s}$, with the entry of significant numbers of non-government organisations (NGOs) into microfinance. This number includes all registered societies, trusts, a few NBFCs and "new generation" cooperatives acting as financial intermediaries. It excludes unregistered self-help groups that are usually established and assisted by the NGOs. It also excludes conventional cooperatives. Initially, many NGO microfinance institutions (MFIs) were supported by donors in the form of revolving funds and operating grants. Lately, development finance institutions such as NABARD, SIDBI and microfinance promotion organisations such as the Rashtriya Mahila Kosh (RMK - the National Women's Fund) have extended bulk loans to MFIs, since 1994. This has resulted in the MFIs becoming intermediaries between the largely public sector development FIs and retail borrowers consisting of groups of poor people or individual borrowers living in rural areas or urban slums. In another model, NABARD refinances commercial banks which in turn finance self-help groups (SHGs) in order to promote relationships between the banks and poor borrowers. This mode has witnessed significant progress over the last 10 years and influenced the rural banking system. Though, in most cases, the organisations earlier involved in developmental works have made a start in providing "user friendly" formal financial services to the poor, gradually transforming themselves into MFIs. Their outreach is still minuscule in comparison with their needs, though. At the same time, the participation of commercial banks in microfinance is negligible both in value terms and in terms of their broader engagement in rural areas.
Since microfinance was taken up mainly as a development initiative, the voluntary development agencies (or NGOs) who were registered either as societies, trusts or Section 25 companies, did not contemplate alternative institutional forms for providing these services - though some cooperatives and one cooperative bank were also engaged specifically in microfinance. As the scale of operations of microfinance activities started growing in value terms and volume terms, the advisability of undertaking such activity on a forprofit basis gained importance. The larger players, in particular, felt a dire need for a transformation in their legal structure. This explains why MFIs in India can now be found in the NBFC format as well.

Of the at least $1,000+$ MFIs in the country today, perhaps 400-500 continue to operate in the form of registered societies or trusts. While institutions like ASA Trust, Tamil Nadu and Nav Bharat Jagriti Kendra, Jharkhand were established initially for a wide range of development activities, some key institutions in the country today were established specifically for microfinance but registered as societies for lack of an appropriate alternative. Examples of these are Swayam Krishi Sangam (SKS), based at Hyderabad and operating in the Telangana region of Andhra Pradesh, and Grameen Koota based in Bangalore and operating in the rural areas near the city. ASA is registered as a trust under the Indian Trust Act as are other institutions such as Mahasemam and Association for Sarva Seva Farms (ASSEFA, also in Tamil Nadu)

Another 300-400 MFIs in India operate as cooperatives either under the conventional state-level cooperative acts, the national level multi-state cooperative legislation or under the new state-level mutually aided cooperative acts (MACS Act). Notable examples of cooperatives operating under the conventional acts are the Annapurna Mahila Cooperative Credit Society in Mumbai, the Indian Cooperative Network for Women (of the Working Women's Forum) in Chennai, Ankuram Sangamam Poram in Hyderabad and Pushtikar Laghu Vyaparik Pratishthan in Jodhpur.

Some of the district cooperative banks - such as DCCB, Bidar (in northern Karnataka) - have also started to take significant interest in microfinance. Of the state-level MACS Acts there has been a significant impact so far only in Andhra Pradesh - which pioneered this regulatory form. There are now many significant Mutually Aided Cooperative Thrift Societies (MACTS) in Andhra Pradesh which, therefore, account for the bulk of the 300-400 players cited earlier. Some better performing examples of such MACTS are the ACTS Mahila MACTS based in Chittoor, the PWMACTS in Vishakhapatnam and the Indur MACTS Federation in Nizamabad.

\section{Latest developments}

More recently, a trend to register MFIs as companies has emerged. Some are registered as not-for-profit companies under Section 25 of the Companies Act, at least partially to take advantage of the Reserve Bank of India's (RBI) exemption from registration for such companies providing microfinance services. Notable examples of these include the Cashpor Microcredit Company Ltd (CMC), based at Varanasi and operating in the eastern part of Uttar Pradesh and west- 


\section{International Journal of Science and Research (IJSR) \\ ISSN (Online): 2319-7064}

Index Copernicus Value (2013): 6.14 | Impact Factor (2014): 5.611

ern Bihar, and Sanghamithra Rural Financial Services Limited (SRFS) based at Bangalore, operating in Karnataka. However, these are still relatively few in number, perhaps no more than ten.

Another form of registration that indicates a bolder, overtly commercial (and in the long term, institutionally more sustainable) approach to microfinance is the establishment of a for-profit company followed by registration with the RBI as an NBFC. A number of MFIs are considering this route and a few have either already transformed into NBFCs or are in the process of doing so. Some of the largest MFIs in the country now operate as for-profit NBFCs. Key MFIs that have already converted their MFI form into for-profit NBFCs (or started as such) are Bhartiya Samruddhi Finance (of BASIX), Hyderabad (operating in the states of Andhra Pradesh, Karnataka, Orissa and Maharashtra), SHARE Microfin based at Hyderabad and operating in the states of Andhra Pradesh, Orissa and Chattisgarh, Spandana, based at Guntur and operating largely in the urban areas of coastal Andhra Pradesh and Sarvodaya Nano Finance (of ASSEFA) , based at Chennai and operating in much of Tamilnadu.

Though a look at the operational profile of each of the NBFCs suggests that transformation of large MFIs into this form has helped them to scale up operations significantly, the form still has significant constraints, particularly in the regulatory limitations on the range of financial services they are able to offer.

\section{Bank loans for micro-finance activities}

In India, banks route micro-credit under various schemes through NGOs / MFIs that operate as financial intermediaries. The ultimate aim of banks is to increase the outreach by financing a large number of Self Help Groups (SHGs).

To avail of finance under the schemes, the constitution of the NGOs/MFIs has to be of any of the following formats, in general:

a) Societies registered under the Societies Registration Act, 1960 or similar State Act.

b) Trusts registered under the Public Trust Act, 1920 or similar Act.

c) Companies registered under the Companies Act, 1956 including Section 25 companies.

d) Non Banking Financial Companies providing financial services to SHGs which satisfy the following criteria as laid down by RBI may only be taken up for financing:

- Engaged in micro-financing activities.

- Licensed under section 25 of the Companies Act, 1956 and not accepting public deposits from the purview of sections 45-IA(Registration), 45-IB (maintenance of liquid assets) and 45-IC (transfer of profits to Reserve Fund) of the RBI Act, 1934.

e) Specialist and other Co-operatives such as Mutually Aided Co-operative Societies, etc.

f) Any other type of institution that offers micro finance and related services may be considered on merits.

\section{Track record}

a) The NGO / MFI should have been in operation for at least 12 months and/or it has a track record of running a successful micro credit programme at least for the last six months.

b) The NGO / MFI should have tied up with a minimum of 200 SHGs.

c) Its activities should be secular in nature.

d) It should maintain a satisfactory and transparent accounting system, MIS and internal audit system.

e) The NGO / MFI should be continuously profit making, if in operation for two years or more. In case it has been functioning for less than two years, the Sanctioning $\mathrm{Au}-$ thority will ensure that the projected profit of the NGO / MFI is sufficient to meet the repayment obligation of the loan.

f) The NGO / MFI should not be a defaulter to any bank / financial institution.

g) Portfolio at risk of the NGO / MFI should be less than five percent (the ratio of the amount overdue for 60 days or more to the total loans on a given date)

h) In case of takeover of NGO / MFI loan from other banks, all the terms and conditions for taking over of the loan will be applicable.

i) NGO / MFI must be transparent in dealing with its borrowers like levying of service and other charges, etc.

j) NGO / MFI should not borrow from other sources for the same project for which loan from the bank is being availed.

k) Loans below INR 200 lacs: The NGO/MFI should achieve minimum scores in the scoring model of the bank. For loans of above INR 200 lacs, they should have valid credit rating from any of the Micro Credit rating agencies, MCRIL, CRISIL, CARE, ICRA and Planet Finance.

\section{Loan Amount}

- Need-based repeat finance.

- Requirement of finance to be worked out based on the health of the NGO / MFI and the business plan as per the appraisal format

\section{Repayment of the loan}

Term loans are repayable in: monthly / quarterly / halfyearly. Instalments depend on the project / purpose. However, total repayment period should not exceed three years. Cash credit loans are to be renewed annually

\section{There is still some way to go}

These things apart, it is by now clear that not all aspects of the functioning of MFIs are above board. Hence what needs to be done is to ascertain how to optimally exploit the MFIs so better financial inclusion can be achieved and the poor are able to access funds at lower costs to take up productive economic activities.

MFIs are ideally placed to fund the requirements of rural beneficiaries like agricultural labourers, small farmers, marginal farmers and rural artisans. Agricultural labourers live a life of uncertainty given that their income is seasonal in nature. Their services are sought during sowing operations and during harvest. Agriculture in India being a gamble with the monsoons, it is possible that their period of employment often gets curtailed. After all, when the monsoons fail, the acreage coming under sowing operations falls steeply. 


\section{International Journal of Science and Research (IJSR) \\ ISSN (Online): 2319-7064}

Index Copernicus Value (2013): 6.14 | Impact Factor (2014): 5.611

\section{Regulatory bottlenecks}

Not being banks, MFIs cannot accept deposits in the conventional form (like saving bank deposits). They can invest the money deposited by customers in money market mutual funds and thus circumvent the law. Though the income generated by such investments is on the low side (lower than the return on savings bank accounts, which is 4 percent now), at least the investment is safe and highly liquid. In fact the product basket can be enlarged by selling personal accident insurance policies and gold coins and rendering special services like international remittances. MFIs can tie up with agencies like Western Union for the purpose.

Given its large basket of products and services, its conspicuous presence in its area of operation and its expertise, MFIs can provide customer-specific solutions which the rural masses badly need today. It is easy to get on the ,personal plane ee with the rural masses and this can help MFIs a great deal in providing a customised package of solutions to them. Proper documentation and storage of these valuable bits of information with the help of information technology could lead the MFIs to introduce new products and services. Ongoing research into these aspects on the part of the MFIs can help them grow and along with them, the beneficiaries can grow too.

\section{Karnataka's MFI scenario}

The Department of Women and Child Development of the government of Karnataka has put in place several programmes for the development of women. The strategy adopted for the programmes in the area of women development involves empowerment of women through education and awareness generation and greater emphasis on vocational training and employment so as to enable them to enter the mainstream of economic development as equal partners. The department implements programmes in the areas of employment, training for women, awareness generation and gender sensitization. The emphasis is on helping women to become self- sufficient and economically independent with the help of training and income generating activities so as to enhance their earning capacity and to bring up their status in life. The department aims at the economic development and integration of women into the main stream of society and also as individuals with a right to human dignity. Besides expanding the on-going programmes, the department has evolved some innovative schemes such as "Stree Shakthi" for empowerment of women and "Santhwana" for providing assistance to victims of various atrocities in the society.

\section{Stree Shakti}

The scheme was launched during 2000-01 with an objective to empower rural women and make them self reliant by inculcating the habit of savings and proper utilization of financial resources.

Anganwadi workers and supervisors are instrumental in organizing rural women in self help groups. About 15 to 20 women who belong to below poverty line families, landless agricultural labourers,

\section{Credit Linkages to SHGs}

As at the end of March 99,969 groups were eligible for credit linkage with banks and also to take up income generating activities. So far 90,182 groups have been credit linked and given financial assistance to the extent of Rs. 496.13 crores.

\section{Income Generating Activities}

74,896 SHGs have taken up various IGA programmes available in other Government Departments namely, Animal Husbandry, Nirmithi Kendras etc., A few of these groups have been given training and technical support under Giriraja Scheme of Animal Husbandry Department. The department has also assisted the SHGs to procure Giriraja birds. So far 14,718 groups have taken up this activity and invested Rs.3.81 lakh towards purchase of Giriraja birds. The different activities taken up are as follows:

\section{1) Dairying}

2) Production and sale of readymade garments

3) Blanket marketing

4) Marketing of seeds and manure

5) Production and sale of
a) Papad
b) Sambar Powder
c) Agarbathi etc.

6) Production and sale of composite manure

7) Production and sale of soap and detergent

Karnataka is among the top five states that collectively account for 59 percent of gross loan portfolio of MFIs. The top five states are West Bengal, Tamilnadu, Karnataka, Maharashtra and UP, in that order.

\section{Review of literature}

1) Piyush Tiwari and S M Fahad in their concept paper "Microfinance Institutions in India", maintain that more than subsidies, the poor need access to credit (Fahad). Absence of formal employment makes them ,nonbankable', so to speak. This forces them to borrow from local moneylenders at exorbitant interest rates. They conclude that the poor repay their loans and are willing to pay interest rates which are higher than those levied by commercial banks provided access to credit is allowed to them. Group pressure and sequential lending motivate prompt repayment and account for extremely low default rates. Secondly, the poor save and hence microfinance should help them to borrow as well as save. These two findings imply that banking on the poor can be a profitable business.

2) Sana Ehsan and Nadia Asghar in the article "Issues in the growth of Micro Finance Banks: Impact of Customer, Internal and External Environment" state that MFIs ${ }^{\text {ee }}$ foremost objective is to reduce poverty within the country by offering loans to the poor (Asghar, 2011). Microfinance banks are the institutions which facilitate the poor class with funds, but they face many issues which are a hindrance. The research article did an analysis of the microfinance banks in Pakistan. The issues that the banks faced in giving loans were categorised under customer, internal and external environment. Upon analysis, it was found that a majority of the issues faced by the banks were because of the customers.

3) Abhijit Banerjee, Esther Duflo, Rachel Glennerster and Cynthia Kinnan in their paper captioned, "The miracle of microfinance? - Evidence from a randomized evalua- 


\section{International Journal of Science and Research (IJSR) \\ ISSN (Online): 2319-7064 \\ Index Copernicus Value (2013): 6.14 | Impact Factor (2014): 5.611}

tion" argue that microcredit has spread extremely rapidly since its beginning in the late 1970s, but whether and how much it helped the poor is a subject of intense debate (Abhijit Banerjee, 2009) This paper reports on the first randomized evaluation of the impact of introducing microcredit in a new market. The Researchers worked with Spandana for the study. Half of the 104 slums in Hyderabad, India, were randomly selected for opening of an MFI branch while the rest were left out. The Researchers show that the intervention increased total MFI borrowing. They studied the effects on the creation and the profitability of small businesses, investment, and consumption. 15 to 18 months after lending began in the areas, there was no effect of access to microcredit on the average monthly expenditure per capita, but expenditure on durable goods increased in treated areas and the number of new businesses increased by a third. The effects of microcredit access were heterogeneous: households with an existing business at the time of the programme invested more in durable goods, while their nondurable consumption did not change. Households with a high propensity to become new business owners increased their durable goods spending and saw a decrease in nondurable consumption, consistent with the need to pay a fixed cost to enter entrepreneurship. Households with a low propensity to become business owners increased their nondurable spending. The Researchers however found no impact on measures of health, education, or women "s decision-making.

4) Anand Rai and Dr. Kanwal Anil in "Financial Performance of Microfinance Institutions: Bank vs NBFC" argue that millions of people in developing countries have been given access to formal financial services through microfinance programs (Anil, 2011). Nevertheless, millions of potential clients still remain un-served and the demand for financial services far exceeds the currently available supply. Further, in order to provide financial services to the poor on a continuing basis, microfinance business needs to be sustainable. It is observed that microfinance organizations have had various degrees of sustainability. One such sustainability is the financial sustainability. The Researchers have attempted to propose a more comprehensive and representative model for financial sustainability and assign due weights to some of the critical financial indicators (like portfolio at risk, loan loss and borrowers per credit officers). Based on the model proposed, a comparative analysis was made of SEWA bank and SKS microfinance (NBFC).

5) Sanjay Sinha in "Microfinance regulation: A more subtle approach" quotes that microfinance in India has grown at close to 100 percent per annum over the past three years to reach around 30 million client accounts (Sinha, 2010). The number of clients served represents a compilation of the number of clients claimed by around 270 MFIs in the country with the leading 25 accounting for around 90 percent of the total. However, what this statistic does not take into account is that the MFIs are competing for easyto-reach customers in urban and densely populated rural areas of southern and eastern India. This has led to a culture of multiple lending increasing the potential for overindebtedness. On the other hand, having noticed a spate of suicides amongst low income families in rural areas, the Andhra Pradesh government had come down with a

heavy-handed ordinance. Studies have shown that suicides by low-income families are attributable to complex socio-economic factors and it is rarely a single incident of coercive collection behaviour by a lender that is the cause. Another solution lies in MFIs registered as nonbank finance companies (NBFCs) which have, until now, only been allowed to provide credit services to their clients, being allowed to provide deposit services as well. Eventually, it will result in a more balanced MFI-client relationship than exists today.

\section{Research Gap}

Impressive though is the reviewed literature, clearly statespecific issues have not been dwelt upon. The contribution of MFIs to women empowerment deserves a deeper treatment which is amiss in the reviewed literature. A perusal of the functioning of the MFIs that intermediate between the financiers and the beneficiaries would add value to the literature that obtains on the subject. In the context of Karnataka, the status of the MFIs is amiss. The contribution of MFIs to women empowerment in the state has to be probed better. Then alone the problems, if any, faced by banks in financing the MFIs that assist the women beneficiaries can be better understood. Grey area concerning the regulatory regime especially the Micro Finance Institutions (Development and Regulation) Bill, 2012 has to be dealt with too in view of its relevance to the growth of MFIs in the state. The recentlylaunched Micro Units Development and Refinance Agency Ltd (MUDRA) has been accorded a mixed reception owing to valid reasons. The present study proposes to plug all these gaps.

\subsection{Need for the Study}

Karnataka is a leading player in the microfinance industry. It is amongst the top five states in the microfinance industry on various parameters as already explained in a previous paragraph. However, the literature on the industry"s status and performance in the state of Karnataka is not in keeping with the state s superior ranking in the industry on various parameters. Hence this study is needed.

\subsection{Scope of the Study}

The study will confine itself to women beneficiaries, microfinance institutions and financing banks based in and around Bangalore.

\subsection{Objectives of the Study}

The objectives of the study will be to:

1) Study the different schemes in place for women empowerment

2) Identify the demerits of the women empowerment schemes

3) Examine the extent to which the women beneficiaries have been empowered under the schemes.

4) Study the role played by the state government and NGOs / SHGs in the disbursement of microfinance in rural Karnataka 


\section{International Journal of Science and Research (IJSR) \\ ISSN (Online): 2319-7064}

Index Copernicus Value (2013): 6.14 | Impact Factor (2014): 5.611

5) Analyse the recently-debated legislation, the Micro Finance Institutions (Development and Regulation Bill, 2012 concerning MFIs

6) Suggest measures and strategies to accelerate the empowerment of women

\subsection{Research Methodology}

By intent, this study will be a descriptive research that uses the survey method. Hence the study will be a fact-finding investigation with adequate interpretation. It will focus on certain aspects or dimensions of the identified problems. The study will be designed to gather descriptive information. Data will be collected by administering Interview Schedules and interviewing the respondents, namely, women beneficiaries, microfinance institutions and financing banks. Data will be analysed using statistical techniques consistent with the objectives of the study. The SPSS package (Statistical Package for the Social Sciences) will be used for the purpose.

\subsection{Hypotheses Proposed to be tested}

The study proposes to test the following hypotheses:

a) The incidence of women beneficiaries borrowing from the informal sector has come down drastically after the microfinance institutions started financing them

b) Women beneficiaries ${ }^{e e}$ standing in society has improved after availing of microfinance

c) Availing of microfinance has promoted the "community feeling" in the women beneficiaries.

d) For the NGOs / MFIs, availing of bank loan for onward lending to women beneficiaries is hassle-free

\subsection{Sampling Plan}

Purposive or judgment sampling under the non-probability sampling method will be employed to select the respondents, namely women beneficiaries, MFIs / NGOs and financing banks. This is because the sample respondents have to conform to certain pre-determined criteria. Women beneficiaries should have borrowed at least once from a respondent microfinance institution. Microfinance institutions must have necessarily financed the respondent women beneficiaries. The respondent banks must have financed the respondent microfinance institutions. Using these criteria, the researcher will select 100 women beneficiaries, five microfinance institutions and five banks. After all, what is important from the point of view of this study is the typicality and specific relevance of the sampling units to the study. Further, this method guarantees inclusion of the relevant elements in the sample. Probability sampling plans cannot give such a guarantee.

\subsection{Sources of Data and Data Collection}

a) Data required for the research will be collected from both primary and secondary sources.

b) Primary data will be collected by administering Interview Schedules to the three categories of respondents, namely, women beneficiaries, microfinance institutions and financing banks. c) Secondary data will be collected from industry bodies / industry associations like the Association of Karnataka Microfinance Institutions (AKMi) and the Microfinance Institutions Network (MFIN). In addition, secondary data will be downloaded from the web sites of the Reserve Bank of India, NABARD, the relevant departments of the government of India, government of Karnataka and the financial press.

\subsection{Analysis of Data}

Non-parametric statistical units will be used to process the data, by using the SPSS package. The methods to be used will include the chi-square test, correlation test and analysis of variance.

\section{Limitations of the Study}

Primary data could sometimes be deduced through constant topic-oriented discussions with the respondents. It is possible that a certain degree of subjectivity, even if negligible, will have clouded their views.

\section{Tentative Chapter Scheme}

The thesis will be presented in chapters, as follows:

\section{Chapter-1: Introduction}

This chapter will introduce the background and nature of the problem. Additionally, it will furnish a statement of the problem and review the related literature. It will explain the scope of the study and define the objectives of the study. Further, it will list out the hypotheses proposed to be tested and conclude with definition of concepts.

\section{Chapter-2: Design of the Study}

This chapter will present all the aspects of the methodology and their implementation. Specifically, it will furnish the methodology followed and the sources of data tapped. It will furnish the sampling plan and explain the data collection instruments used. It will also furnish the data processing and analysis plan and disclose the limitations of the study.

\section{Chapter-3: Profile of the respondents}

This chapter will profile all the three categories of respondents, namely, women beneficiaries, microfinance institutions / NGOs / SHGs and the financing banks.

Chapter-4: Functioning of the credit delivery system vis-àvis the women beneficiaries

This chapter will study the functioning of the credit delivery system vis-a-vis the women beneficiaries that the study focuses on.

Chapter-5: Effectiveness of credit utilization by the respondent women beneficiaries

This chapter will examine how effectively the respondent women beneficiaries have utilised micro-credit.

Chapter-6: Women beneficiaries' exploitation of the microfinance mechanism and the schemes under it for their empowerment. 


\section{International Journal of Science and Research (IJSR) \\ ISSN (Online): 2319-7064 \\ Index Copernicus Value (2013): 6.14 | Impact Factor (2014): 5.611}

Microfinance cannot be successful unless and until the targeted beneficiaries exploit the microfinance mechanism as also the schemes under it optimally. Hence this chapter examines how the targeted women beneficiaries exploit the microfinance mechanism as also the schemes under it for their empowerment.

Chapter-7: Role of the state government and NGOs / SHGs in the disbursement of microfinance in rural Karnataka A welfare programme like micro-finance cannot succeed unless and until the state government and NGOs / SHGs play their role to perfection in the disbursement exercise. Hence this chapter studies the role of the state government and NGOs / SHGs in the disbursement of microfinance in rural Karnataka.

Chapter-8: The Micro Finance Institutions (Development and Regulation Bill, 2012

The Micro Finance Institutions (Development and Regulation) Bill, 2012 has been put into cold storage owing to reservations expressed by the various stakeholders associated with the micro-finance industry. This chapter analyses the debated provisions o the Bill. Additionally, the chapter reviews the functioning of the Micro Units Development and Refinance Agency Ltd (MUDRA), in the light of its avowed objectives.

Chapter-9: Summary, Conclusions and Recommendations This chapter will furnish the findings and conclusions of the study after a brief statement of the problem, the purpose of the study and the methodology used in the investigation.

\section{References}

[1] Abhijit Banerjee, E. D. (2009). The miracle of microfinance? Evidence from a randomized evaluation. Massachusetts: MIT Department of Economics and NBER.

[2] Aghion, A. d. (2004). Microfinance: Where do we stand? London: Macmillan/Palgrave.

[3] Anil, A. R. (2011). Financial Performance of Microfinance Institutions: Bank vs NBFC. International Journal of Management and Strategy .

[4] Anupam Basu, R. B. (2004). Anupam Basu, RodMicrofinance in Africa: Experience and Lessons from Selected African Countries. Washington: International Monetary Fund.

[5] Aportela, F. (1999). Effects of Financial Access on Savings. Mexico: Banco de México.

[6] Asghar, S. E. (2011). Issues in the growth of Micro Finance Banks: Impact of Customer, Internal . INTERDISCIPLINARY JOURNAL OF CONTEMPORARY RESEARCH IN BUSINESS , 10091021.

[7] Basu, P. a. (2005). Scaling-Up Microfinance for India's Rural Poor. Social Science Research Network .

[8] Bateman, M. (2010). Why microfinance doesn't work. London: Zed Books.

[9] Between „Empowermente and „Liberation“: The Kudumbashree Initiative in Kerala. (2007). Indian Journal of Gender Studies , 33-60,.

[10] Chakrabarti, R. (2004). The Indian Microfinance Experience - Accomplishments and Challenges.
Hyderabad: University Press, Insdian School of Business.

[11]Christen, E. R. (1999). Microfinance Enters the Marketplace. Washington D.C: U.S Agency for International Development.

[12] Fahad, P. T. (n.d.). Concept Paper: THE GLOBAL DEVELOPMENT RESEARCH CENTER. Retrieved August 14, 2014, from THE GLOBAL DEVELOPMENT RESEARCH CENTER Web site: http://www.gdrc.org/icm/index.html

[13] George, M. (2009). A Primer on Microfinance in India. Microfinance Gateway, 37.

[14] Ghate, P. D.-G. (1992). Informal finance: Some findings from Asia. Oxford: Oxford University Press.

[15] Ghosh, R. (2005). Microfinance in India: A Critique. New York: Social Sciene Research Network.

[16] Government of India. (2011). Sex Ratio in India. New Delhi: Census 2011.

[17] Jegede, C. A. (2011). Impact of Microfinance on Poverty Alleviation in Nigeria: An Empirical Investigation. European Journal of Humanities and Social Sciences , 97-111.

[18] Jonathan Williams, J. C. (1998). Money: A History. London: St. Martin's Press.

[19]Kereta, B. B. (2007). Outreach and Financial Performance: Analysis of Microfinance Institutions in Ethiopia . African Economic Conference (pp. 1-31). Addis Ababa: United Nations Conference Center (UNCC).

[20] Khachatryan, K. (2010). Financing Microfinace Institutions: inpact an Organizational Strategy an Proformance: Philosofical and Methodological Implications. GREDEGCNRS: SKEMA Business School Campus Shopia-antipolis.

[21]Lash, N. (2008). Asymmetric Finance: Issues in Micro Finance. Journal of Asymmetric Economics, , 1.

[22] Marcella Corsi, F. B. (2006). Women and Microfinance in Mediterranean Countries. Development, 67-74.

[23] Microfinance Information Exchange. (2006). Performance and Transparency: A Survey of Microfinance in South Asia. Washington: Microfinance Information Exchange.

[24] Microfinance Institutions Network (MFIN). (2015). Highlights: Portfolio. Micrometer, 6.

[25] Miguel Delfiner, A. G. (2009). Public Policy on Microfinance in South America. Munich: University Library of Munich.

[26] Ministry of Labour \& Employment, Government of India. (2014-15). Annual Report, 2014-15. New Delhi: Ministry of Labour \& Employment, Government of India.

[27] Ministry of Women and Child Development, Government of India. (2001). NATIONAL POLICY FOR THE EMPOWERMENT OF WOMEN . New Delhi: Government of India.

[28] Morduch, J. (1999). The role of subsidies in microfinance: evidence. Journal of Development Economics , 229-248.

[29] Nair, A. (2005). Sustainability of Microfinance Self Help Groups in India: Would Federating Help? Washington, D.C: World Bank Publications. 


\section{International Journal of Science and Research (IJSR) \\ ISSN (Online): 2319-7064}

Index Copernicus Value (2013): 6.14 | Impact Factor (2014): 5.611

[30] Nava Ashraf, D. K. (2010). Female Empowerment: Impact of a Commitment Savings Product in the Philippines*. World Development, 333-344.

[31] PANDE, R. B. (2005). Do Rural Banks Matter? Evidence from the Indian Social . The American Economic Review, 780-795.

[32] Queiroz, M. d. (2006, December 7). MIGRATIONPORTUGAL: Starting a New Life With Microcredit. Inter Press Service News Agency, p. 1.

[33] Robinson, P. D. (2009). Savings Constraints and Microenterprise Development: Evidence from a Field Experiment in Kenya. American Economic Journal: Applied Economics, 163-92.

[34] Rutherford, J. M. (2003). Microfinance: analytical issues for India. Oxford: Oxford University Press.

[35] Sa-Dhan-The Association of Community Development Finance Institutions, New Delhi. (2005, December). Publications: Sa-Dhan. Retrieved August 14, 2014, from Sa-Dhan Web site: http://www.sadhan.net/Adls/Microfinance/Article/Publications/Existin gLegalRegulatoryFramework.pdf

[36] Sharma, P. R. (2007). Micro-finance and Women Empowerment. The Journal of Nepalese Business Studies, 16-27.

[37] Sinha, S. (2010). Microfinance regulation: A more subtle approach. New York: Microfinance Club.

[38] Tilburg, H. A. Rural microfinance between clients and financial markets. Groningen: University of Groningen.

[39] Upadhyayula, M. S. (n.d.). The Transformation of the Microfinance Sector in India: Experiences, Options, and Future . Journal of Microfinance, 90.

[40] Vicki Bogan, W. J. (2007). Does Capital Structure Affect the Financial Sustainability of Microfinance Institutions. Ithaca: Cornell University.

[41] Yunus, M. (2002). Grameen Bank II: Designed to Open New Possibilities. Dhaka: The Grameen Trust.

[42]Zinman, D. K. (2010). Expanding Microenterprise Credit Access: Using Randomized Supply Decisions to Estimate the Impacts in Manila. Review of Financial Studies , 433-464. 